\title{
マグネットメータによる高炉内部状態の観測 ${ }^{\dagger}$
}

\author{
原 田 耕 介**小島 佑 介**. 藤 井 義 博**. 竹 内 信次郎***
}

Measurements of Blast Furnace Inner-States by Magnetometer

Kosuke Harada*, Yusuke Kojima**, Yoshihiro FujII** and Shinjiro Takeuchi***

\begin{abstract}
We present in this paper a new and direct method of measuring the inner-states of the blast furnace. The key point of this method is that a number of magnetometers installed in the furnace detect the layers of the ores and coke through a disturbance of the magnetic field distribution. By processing the outputs from these multi-magnetometers, we can have various important clues for the control of the blast furnace, such as the falling speed and the thickness of the layers, etc. We develop the magnetometer suitable for the application, which is made of a small Mo permalloy film.
\end{abstract}

\section{1. 緒言}

高炉は，Fig. 1 亿示すどとく, 原料の鉄鈗石（焼 結鉱）之燃料でかつ還元材料のコークスを交互に層状 に炉頂部から装入する，乙の積層された鉣石は，炉下 部の羽口から吹込んだ熱風之コークスの反応により生 じる還元ガスによって加熱還元されつつ降下してい き，銑鉄となって滴下し，炉底部に溶銑として貯えら れる。

この高炉を操業するうえで, 内部状態と装入物の挙 動を把握することが非常に重要である..しかし, 高炉 は厚い耐火物之鉄皮で包まれた密閉構造であり，還元 は高温で行われるため, その状態と挙動を正確に観測 することができなかった，わずかに，高炉炉頂部の装 入物表面の分布形状を ITV で観察する方法, あるい は測距離計で観測する方法があり，また高炉炉頂部の ガス流の分布や温度分布を計測して装入物の挙動を推 定する方法が開発されている. しかし, いずれの方法

† th IMEKO Cogress で発表 (昭 54・5)

* 九州大学工学部 福岡市東区箱崎 6-10-1

** 新日本製鉄(株)堺製鉄所 堺市築港八幡町 1-1

*** 三島光産 (株) 北九州市八幡東区枝光町

* Faculty of Engineering, Kyushu University, Fukuoka

** Nippon Steel Corp., Sakai

*** Mishima-Kosan Co., Ltd., Kita-kyushu (Received November 2, 1979)

(Revised January 7, 1980)



Fig. 1 Illustration of the blast furnace

あ装入物の包括的な挙動を間接的汇測定する手段であ り, 塊状帯および融着帯での装入物自身の挙動を直接 に計測する手段ではなかっだ.

本論文では，炉内の内部状態と装入物の挙動を直接 計測する新しい方法を提案する. この方法のキーポイ ントは，鉱石層とコークス層が励磁用静磁界中を降下 するとき，鉱石とコークスの透磁率の違いによって交 番的に磁界が変化する物象を, 炉壁に装着したマグネ ットメータで計測するととにより, 装入物の挙動を直 接観測するととが可能な点にある。

\section{2. 本論}

高炉の頂部から装入された鉱石とコークスは上昇し てくる還元性ガスと反応しつつ降下する．鉱石の温度 は, 高炉シャフト上部を通過する間は, 炉壁近傍で は $200^{\circ} \mathrm{C}$ 末満であり, Fig. 2 で示すようにての温度 域では,な搔磁性を保持している。

すなわち，高炉の中段より上方の塊状帯と呼ばれる ゾーンに括いては，鉱石とコークスの透磁率の差異は 顕著であり，ての差違を利用して鉱石とコークスの識 別と挙動の検出をするととが可能である. 


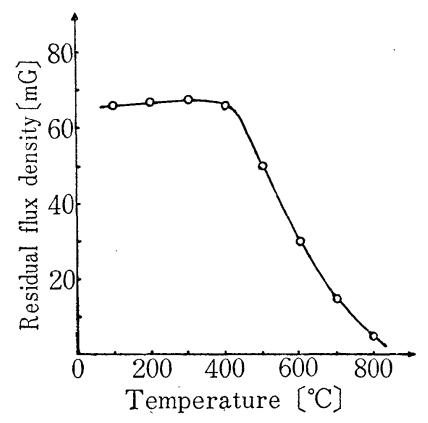

Fig. 2 The relation between the remnant magnetism and the temperature (Ore's weight $1310 \mathrm{~g}$ )

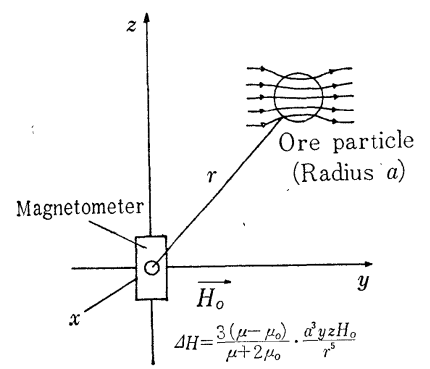

Fig. 3 The geometry of the magnetometer and an ore particle

ここで，以下の検討の基本となる，マグネットメー タと計測対象の焼結鉱の座標系を Fig. 3 に示す.

指向性をむつ磁気検出器の検出軸を高炉の装入物の 降下方向 ( $z$ 軸) と平行させ, 加一様な磁界 $H_{0}$ を $z$ 軸と直交する方向に配置し，乙のとき検出する磁界 偏移を考察する. 粒子半径 $a$, 透磁率 $\mu$ の焼結鉱が $y-z$ 平面上で検出器から離れた点に存在する場合, 検出器の位置（原点）に打磁界 $\boldsymbol{H}$ は

$$
\begin{aligned}
& \boldsymbol{H}=\left(1-\frac{\mu-\mu_{0}}{\mu+2 \mu_{0}} \cdot \frac{a^{3}}{r^{3}}\right) \cdot \boldsymbol{H}_{0}+\frac{3\left(\mu-\mu_{0}\right)}{\mu+2 \mu_{0}} \cdot \frac{a^{3} y H_{0}}{r^{5}} \cdot \boldsymbol{r} \\
& \boldsymbol{r}=y \boldsymbol{j}+z \boldsymbol{k} \\
& r=|\boldsymbol{r}|=\sqrt{y^{2}+z^{2}}
\end{aligned}
$$

で与えられる.ここに

$$
\begin{aligned}
& \mu_{0}: \text { 真空透磁率 } \quad \mu: \text { 鉱石の透磁率 } \\
& a: \text { 鉱石の粒子半径 } \quad r: \text { 鉱石〜検出器間距離 } \\
& \boldsymbol{j}: y \text { 軸方向単位ベクトル } \\
& \boldsymbol{k}: z \text { 軸方向単位ベクトル }
\end{aligned}
$$

このとき検出器の指向性によって, 磁界の変化分とし て検出するのは一様磁界亡直交する $z$ 成分の $\Delta H$ で ある。

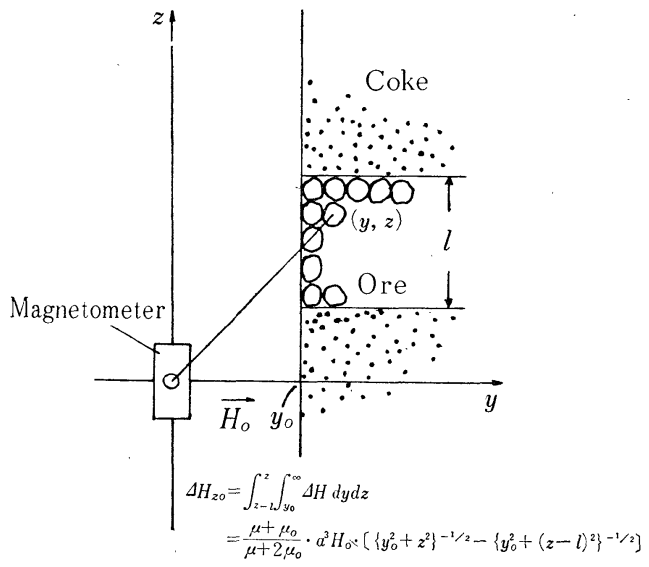

Fig. 4 The schematic measuring principle



Fig. 5 The ore layer's position

$$
\Delta H=\frac{3\left(\mu-\mu_{0}\right)}{\mu+2 \mu_{0}} \cdot \frac{a^{3} y z H_{0}}{r^{5}}
$$

高炉では, Fig. 4 のごとく, 装入物は $z$ 方向に積 層状態を構成し, 炉中心方向 (y 方向) には磁気検出 器から見れば無限長の広がりをもつと考えて良い.い ま,一つの鉱石層の厚みを $l$ とすれば, $y-z$ 平面上 の鉱石により生じる磁界偏移は次式で与えられる.

$$
\begin{aligned}
\Delta H_{z 0} & =\int_{z-l}^{z} \int_{y_{0}}^{\infty} \Delta H d y d z \\
& =\frac{\mu-\mu_{0}}{\mu+2 \mu_{0}} \cdot a^{3} H_{0} \cdot\left[\left\{y_{0}^{2}+z^{2}\right\}-\frac{1}{2}\right. \\
& \left.\cdot-\left\{y_{0}^{2}+(y-l)^{2}\right\}-\frac{1}{2}\right]
\end{aligned}
$$

この磁界偏移は Fig.5 のどとく表わされ， $z=0$, $z=l$ の鉱石層界面近傍で最大最小をむつ. 以上 $y-z$ 平面のみで考察したが, 実際には鉱石層は $x$ 方向にむ 拡がりをもつ. しかし， $x$ 方向の拡がりの効果は上記 $y-z$ 平面の重祮合わせとして作用するので, $z$ 方向 

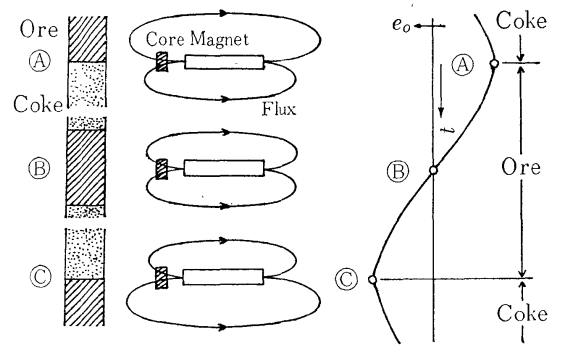

Fig. 6 The principle of detecting ore and coke

に積層した鉱石層の境界において最大最小を検出する 点では変化はない.

さて，高炉においては，積層した鉱石層・コークス 層の一連の層が順次降下するため, 前述の距離の関数 としての磁界の変化が時間の関数として Fig. 6 のよ うに観測される。最小点(から最大点@までの期間が 釷石層の通過を, 逆に最大点(からつぎの最小点(Aま でがコークス層の通過を示している.

\section{3. 高炉用マグネットメータ：磁気マルチ センサ}

前章で考察したごとく, 原理的には一様な平行磁界 中を鈗石層とコークス層が降下することによって生じ る微小な磁界偏移を計測するととによって, 鉱石とコ ークスの識別と挙動の検出が可能である. しかし, 高 炉内部を観測するためには高感度で指向性に優れてい ることの他に, 雾囲気温度の変化に耐える良好な温度 特性と, 伝送損失を防ぐためには, 直流電源で直流信 号伝送が望ましく，さらに炉体装着が容易なように小 形化が必要である.

以上の目的化合致する磁気検出器として, 新しく磁 気マルチ形マグネットメータ ${ }^{2)} 32$ を開発した. 本マグ ネットメータの回路を Fig. 7 に示す.

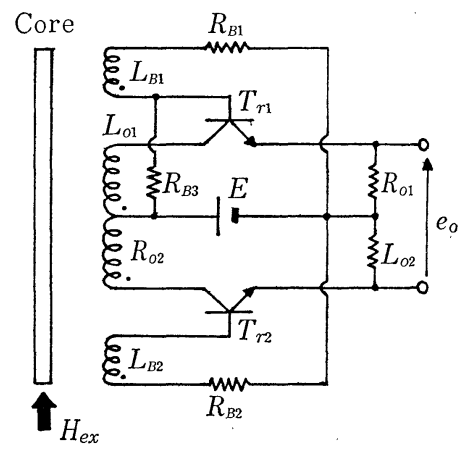

Fig. 7 The circuit of the magnetometer

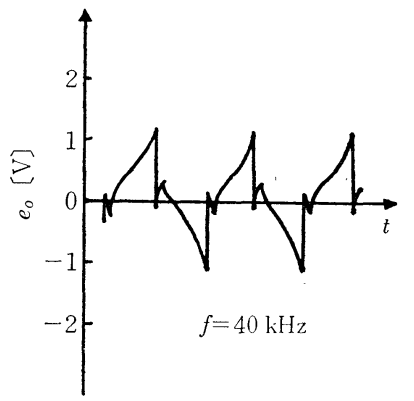

Fig. 8 The waveform of the magnetic oscillation of the magnetometer

対をなす二つのトランジスタ $T_{r 1}$ と $T_{r 2}$ が厚さ $25 \mu \mathrm{m}$ の $M_{0}$ パーマロイ薄膜をボビン状に巻いたコ アを交互に励磁するスイッチングトランジスタとして 作用する磁気マルチ回路である. Fig. 7 において, 電 源 $E$ が入ると $E \rightarrow R_{B 3} \rightarrow T_{r 1} \rightarrow R_{01} \rightarrow E$ の経路で電 流が流れる.との電流によって $T_{r 1}$ のコレク夕電流 は $R_{01}$ を通って $L_{01}$ に流れ，コイル $L_{B 1}$ に誘起電 圧が発生し $T_{r 1}$ は導通状態となる。一方， $T_{r 2}$ はコ イル $L_{B 2}$ に誘起する逆極性電圧のため, 不導通状態と なる。この状態がしばらく続いた後に, 磁心の $B H$ マイナーループの非直線性により, $d \phi / d t$ の值が次



Fig. 9 The detecting property of the magnetometer

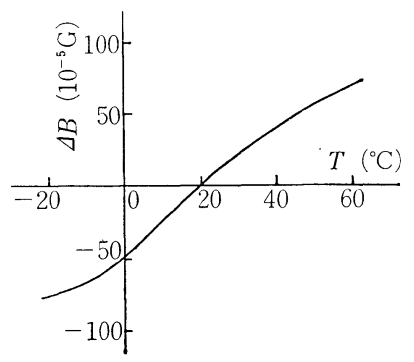

Fig. 10 The temperature sensitivity of the magnetometer 


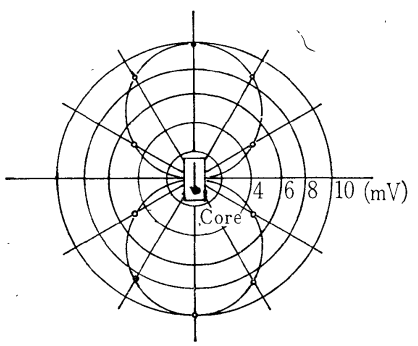

Fig. 11 The directivity of the magnetometer

第に小さくなり $T_{r 1}$ のベース電圧はカットオフ電庄 まで下がる.乙れにより $T_{r 1}$ のコレクタ電流は減少 し, ついには $T_{r 1}$ は不導通となりコアの磁束レベル は外部磁界 $H_{e x}$ で規定される磁束レベルまで戻ろう とするため, 逆にコイル $L_{B 2}$ に逆極性の誘起電圧が 発生し $T_{r 2}$ が導通状態に入る.

以後この動作を繰り返して磁気発振が起こり, 外部 磁界 $H_{e x}$ によって規定される磁束レベルを中心にし てコアの磁束が変化することから， $R_{01}$ と $R_{02}$ に流 れる電流の平均值む $H_{e x}$ ，によって制御される，Fig 8 は，Fig. 7 亿示した回路の発振波形である.乙の状 態は $H_{e x}=0$ であるが, $H_{e x}$ が印加されれば各半サ イクルの周期が $H_{e x}$ で制御され，直流分が $e_{0}$ に重 畳されるととになる.

Fig. 9 に本マグネットメータの磁気検出特性を示 した．ヒステリシスのない良好な直線性を，有し，200 $\mathrm{mV} / \mathrm{G}$ の高感度をむっている.

Fig. 10 亿温度特性を示す. 基準点を $20^{\circ} \mathrm{C}, \Delta H_{e x}$ $=0$ として, 温度係数は $2 \gamma\left(10^{-5} \mathrm{G}\right) /{ }^{\circ} \mathrm{C}$ であり, 既存 ホール素子の 1000 倍以上の安定性をむつ.

Fig. 11 に指向性を示す.コアの軸方向に高い感度 をもち、コアと直交する磁界には感じない優れた特性 をもっている。

\section{4. マグネットメータの高炉への実装}

マグネットメータを高炉の炉体に装着するには，マ グネットメータとともに装入物を励磁する磁界発生器 をコンパクトにー体化することが, 高炉のガスシール



Fig. 12 Installation of the magnetometer

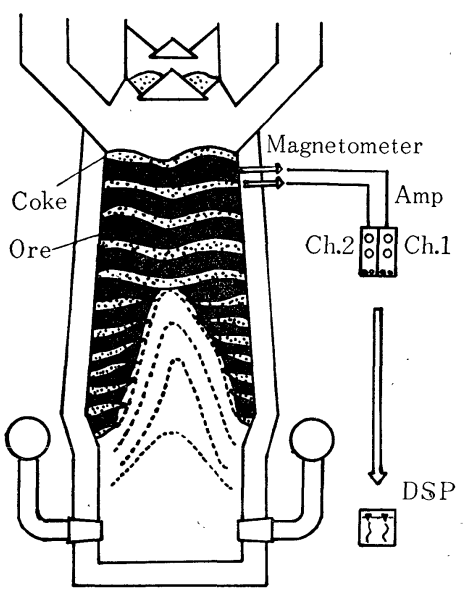

Fig. 13 Schematic magnetometer system

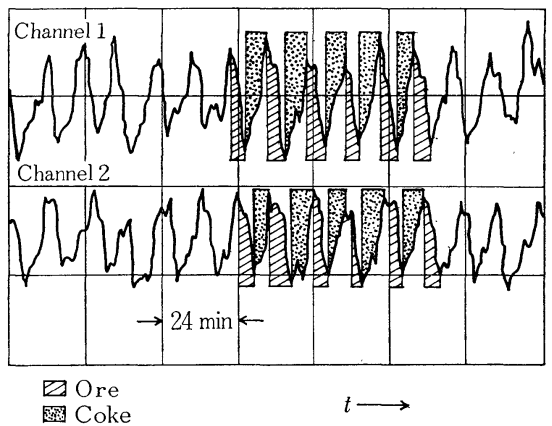

Fig. 14 The waveforms of the magnetometers

性および検出部の泠却の容易さから強く要求される. したがって，実際に高炉に装着したマグネットメータ は Fig. 12 のどとくステンレス (SUS 304) の二重水 冷管の中にマグネットメータのコアを，スイッチング トランジスタ等の発信回路と分割して, 永久棒磁石の 磁界中心軸上の先端に配置し，乙の3者を樹脂で一体 に固めた構造とした。

Fig. 13 は降下速度を求めるために炉高方向に 400 $\mathrm{mm}$ の距離をむって，ペアで炉壁レンガに装着したマ グネットメータの実装概観図である.

Fig. 14 は Fig. 13 に示したペアのマグネットメー 夕の出力波形である. チャネル 1 , チャネル 2 の波形 は，それぞれペアのマグネットメータの上段および下 段からの出力を示す. 両波形の位相差が，ペアのマグ ネットメータ間を装入物が降下するのに要する時間を 与えるから, 装着距離より容易に装入物の降下速度を 導くことができる. Fig. 14 の例では, 約 $6.5 \mathrm{~m} / \mathrm{H}$ の 降下速度を示している. また，降下速度に鉱石・コー クス各層の通過に要する時間（最大值～最小値, 最小 




Fig. 15 The waveforms of the magnetometers installed in the circumferential direction of the blast furnace

值〜最大值の経過時間）を乗算するととによって, 各 層の層厚が計算できる. Fig. 14 の例では, 鉱石とコ 一クスの層厚は, 両者とあ約 $50 \mathrm{~cm}$ を示している.

さらに, マグネットメータを高炉の円周方向に配置 するととによって，装入物の積層状態の円周方向での バランスを計測するととができる．Fig. 15 は $180^{\circ}$ 対向した位置に配置した二つのマグネットメータの出 力波形を示す. チャネル 3 がチャネル 4 より, 当初は 先行して降下していたが，約 3 時間経過する過程で,

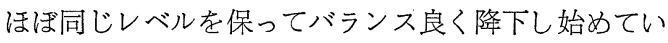
る.

\section{5. 結}

論

以上, 高炉炉内の装入物の積層状態と降下状態を直 接計測する手段として, 新しく開発したマグネットメ


を用いることによって，炉壁近傍における装入物の降 下速度拉よび鉱石，コークス各層の層厚を計測するて 之が可能であるととあに，円周方向に複数個配置する ことにより高炉内反応の円周バランスを把握するとと 屯可能となり, 既存の装入物の分布制御や羽口支管風 量制御を真にクローズドループ化するととすに，マグ ネットメータ情報に基づく新しい高炉操業技術も展開 されつつある.

\section{参考 文 献}

1）神原健二郎，他：高炡解体調查之炉内状況，鉄乙鋼，62 $-5,535 / 558(1976)$

2）原田耕介, 他: 磁気マルチ形磁力計, 昭和 50 年度電気 学会全国大会, No. 195 (1975)

3) K.Harada, et al. : The Magnetic Mixing Amplifier, IEEE Trans. on Magnetics, MAG-8-4, 780/785 (1972)

4）原田耕介，他：マグネットメータによる高炻内部状態の 観测, 第 16 回 SICE 学術講演会予稿集, 669/670 (1977)

5) K. Harada, et al.: Measurements of Blast Furnace Inner-States by Magnetometer, 8th IMEKO Congress, S-25 (1975) 